\title{
PRESS AND THE DIGITAL REVOLUTION: THE CHALLENGES OF THE PORTUGUESE MARKET
}

\author{
Elsa Costa e Silva ${ }^{1}$
}

\begin{abstract}
In a context of digitalization and economic crisis, Portuguese newspapers are struggling to survive in an adverse scenario. The figures for paid circulation and advertising revenues show a decreasing operational business, aggravated by the fact that Portugal is a small market with traditional low levels of readership. Digital strategies and the search for other nontraditional revenues are in place, but newspaper companies have not managed to achieve new levels of revenues that replace the loss in circulation and advertising.
\end{abstract}

In the aftermath of the Portuguese democratic revolution, that abolished in April 1974 a 48-year-old dictatorship, newspapers gained a central role in the political and social struggles that followed the newly established democracy. Journalism was a very dynamic force in the political debate and even an armed tool used by all parties in the political turmoil. Some newsrooms were occupied, showing the tensions within newspapers between personnel more connected to the communist party and the more moderate ones, closely linked to socialist wings. In the summer of 1975, right before a new (failed) revolutionary attempt tried to install a communist system in Portugal, a wave of anti-communist

1 Elsa Costa e Silva is an assistant professor in Communication Sciences and a researcher at the Communication and Society Research Center at the Universidade do Minho, Portugal.

Recherches en communication, $\mathrm{n}^{\circ} 44$ - Article published on 23/11/2017 
manifestations took place in Portugal (attacking Union's offices and buildings of the communist party) with "revolutionary" newspapers being burned in street bonfires.

The stabilization of the political life in Portugal was accompanied, mainly in the 1980s, by a growing professionalization and qualification of newsrooms, which were gradually being de-politicized (from a party point-of-view) and becoming more independent from political orientations. Since the period known as the "hot summer of 1975", newspapers probably never experienced another time in which they have been at the center of a revolutionary setting. Nor have they had a golden period of so much paid circulation. But the business of print journalism grew and stabilized in the 1990s, with newspapers gaining a more economic product penchant than a political one. Until it was caught up again by a new revolution, this one of a technological nature, that is burning more than just paper, since it may be also incinerating the whole idea of what newspapers are, as well burning out its traditional business model.

Besides this technological transformation, the Portuguese press is, at the moment, facing a context of economic crisis. Operating in a small market, newspaper companies suffer in addition constraints from the traditional low levels of readership in Portugal. The crisis of Portuguese newspapers has made some headlines and the purpose of this paper is to register and describe the challenges faced by Portuguese newspapers, in a context of a digital revolution and considering its small market, as well as to identify strategies used by companies to remain relevant to their reader and to advertisers in order to maintain revenues.

\section{A paradigmatic change}

The press is being challenged worldwide by a paradigmatic change (Picard, 2008 and 2010; Franklin, 2008a). Newspapers have been set with a date do die (see, for instance, Meyer, 2009) and several researchers consider that the transition from paper to online is mandatory in order newspapers to survive somehow (Tremblay, 2014). The future is anything but clear and factors 
threatening the newspaper industry are of different nature: a dying business model, social and cultural changes in news consumption in the digital era and the questioning of journalists' role in setting the agenda.

More than just the end of a medium, the possible death of newspapers may also mean that a particular way for people to get informed is doomed. The functions performed by newspapers in democratic societies are not fully assumed by other media, and the crisis faced by newspapers may have negative implications for democracy by undermining the watchdog role it traditionally plays (Siles \& Boczkowski, 2012). Newspapers have been a source of valuable information about public and social affairs, that support the informed political decisions of citizens and have provided meaningful investigation on the concentration of power by various institutions (Schudson, 2008). Newspapers have been proven to turn local politics more vibrant (Schulhofer-Wohl and Garrido, 2009) and have been closely associated with the support of national and cultural identities (Dekavalla, 2015). With technology fostering the increasing fragmentation of audiences and the dispersal of advertising revenues to other platforms, newspapers are faced with new actors disputing their role to inform, to gather audiences and to provide for a for civic debate. In the context of the information abundance that characterizes the Internet, newspapers see themselves undermined by the fragmentation of media and the diversification of its platforms.

However, the death of newspapers is still to be fully determined. National, political and social conditions are essential to explain the trend in newspaper consumption (Wasserman, 2008) and this movement of vanishing is not a worldwide reality (Franklin, 2008b). Meanwhile, even if the news printed in a newspaper may be facing an end, news still make their way out to the public through online services. However, digital outlets have proved not to be fully equivalent to printed products. Fostered by technology, immediacy is becoming an increasingly relevant value in newsrooms. This policy to prioritize the online has been associated with a decline in quality (Franklin, 2008b). More importantly, web metrics now allow for an online audience 
tracking and are influencing what is published (McGregor, 2007; Tandoc, 2014) which can mean more and more soft news with high entertainment value, but not so much news in relation to serious public affairs (Nguyen, 2013).

The Internet has disrupted traditional business models, affecting both sales, incomes and advertising revenues. A culture of free content has been established in the internet and a majority of newspapers have been delivering information for free. And while online news is yet to prove advertisers of its value, users show themselves very resistant to pay for a product they have been getting for free (Nguyen, 2013; Picard, 2008; Casero-Ripollés \& Izquierdo-Castill, 2013). No durable solution on how to monetize online content has been presented by newspapers, which are still in the dark on how to reinvent themselves on a digital platform.

From an economic point of view, newspapers are said to have outdated business models, being too dependent on advertising. The crisis that unfolded since 2008 has had major consequences for firms and groups, in a context of a high financialization of the media business (Fiztgerald, 2012), which has made it more difficult for news organizations to meet their debt payments (Siles \& Boczkowski, 2012). Financialization has been described as one of the central features of media groups and highlights "the extraordinary growth in the size of the financial sector and financial assets relative to the industrial and other sectors of the economy over the past 25 years and especially since the mid1990s" (Winseck, 2010). One of the major consequences of the enunciation of the crisis has been the reduction of newsrooms staff and resources, even though if such groups still presented a profit in their annual reports (Silva, 2014).

The adaption to the digital environment has lead some newspapers to adopt paywalls that allow them to retrieve value from readers: by the subscription value and by the collection of data presented at the registration, to sale targeted advertising (Doyle, 2013). Advertising revenues may still be available for newspapers in a digital environment, but this implies significant changes in the focus of newspapers, argues Berte \& De Bens (2008). Local focus and targeted approach can differentiate newspapers from 
other news outlet. Another strategy is newspapers to develop their own classified websites or websites in areas of business that complement their title. Other non-traditional revenues may come from innovative approaches, such as creating subscription-based clubs or commission on sales of goods (Doyle, 2013).

However, the internet is not considered to be the main and only reason for the announced possible demise of newspapers. Bob Franklin (2008b) argues that sociological accounts are far more relevant to explain the decline in titles and readers, as lifestyles influence directly the patterns of consumption. Newspaper reading was already declining before the internet disrupted the business model as it can be seen, for instance, in the death of most evening papers. Online stories typically are shorter and more fact-based than print stories, which tend to value contextualization and more profound explanations. But even before online news consumption was a daily habit for readers, page size in print papers had shrunken, more photography was being used and fewer words were being printed - which was particular in the case of case the free newspapers.

Research focusing on the future of newspapers and on the possible competitive advantages of this medium has stressed their reinforced civic role in the local context, particularly in the case of print editions. Facing an era of fragmentation and diversification, citizens with strong attachment to the community are more likely to turn to newspapers, namely their print editions (Skogerbo \& Winsvold, 2011). Hyperlocal coverage, as means to satisfy the needs of smaller communities, has been considered to hold the potential for sustaining viable business models (Parasie and Cointet, 2012) as it seems that newspapers are perceived to be the best positioned medium to serve this civic role.

So, even if the future of newspapers is more open than predicted by some academics, significant changes are taking place, with consequences in terms of professional practices, news consumption and of the quality of journalism. Bearing thus in mind that the impact of internet is not only felt at the business level, it is also clear that the business model is one of the most pressing elements determining the future of newspapers. And this 
business model, in the case of countries like Portugal, still has to accommodate the fact that it is intended for a small market which further narrows down the perspectives.

\section{Small Markets}

In most recent research, small states tend to be overlooked although they do provide valuable information for the comprehension of various social phenomena (Puppis, 2009; Veenendaal \& Corbet, 2015). Even though the issue of smallness is not frequent, it has not been absent from the scientific concerns that have pointed out some possible relevant outcomes of the lack of resources and strong markets (Puppis et al., 2009; Schlesinger $\&$ Benchimol, 2015). Small markets are not a unique condition of small states and smallness has also been studied in regard to the local structure of the newspaper business in the USA stressing its bonds to the community (Picard, 2008), to the specific identity of a given community (Dekavalla, 2015) or in regard to different linguistic communities within the same state (Prado, 2015).

In the particular case of media industries, small markets may enhance some perils and risks to the pursuit of the public interest by the media and present added challenges to regulation. Puppis (2009) lists four structural peculiarities of small media markets: shortage of resources (capital, know-how and professionals); small audience markets and small advertising markets (which, in face of the high fixed productions costs, typically affecting the media, leaves less for realizing economies of scale); dependence (less capable of responding to the globalization movement or to any adverse political decisions of big neighbours or of the EU); and vulnerability (to the threats of foreign operations, such as takeovers of media companies or the importation of media products).

In most cases, in small media markets there seems to be less political will to limit concentration of media ownership. In an analysis of the U.S. market, Picard (1988) found that concentration increases as the size of the market decreases. Mergers are important corporative operations that aim at obtaining 
synergies and economies of scale and this is not only achieved at the audience level. By increasing the potential readers market, mergers also contribute to make the newspapers more attractive to advertisers, but this situation is potentially more problematic in small media markets (Berte \& De Bens, 2008). Small markets tend to be more concentrated, which may be a risk in terms of diversity of supply and for political pluralism. Chambers (2003) provides evidence that there is a tendency for the loss of voices in concentrated small markets and that the deregulation of media markets led to a decrease in the overall number of owners in small markets.

When considering small markets for audience and advertising, national publishing firms have to deal with the possibility of foreign competitors being more efficient and thus conquer a significant share of the market, particularly in the case of markets sharing languages with big neighbours. On the other hand, publishing firms of small states have to invest approximately the same amount of money per newspaper prototype, thus incurring the same fixed costs of production, but they have lesser distribution profits since the potential audience is smaller.

The provision of media in a country is significantly affected by two factors: the size and wealth of the economy as a whole and the level of media consumption (like readership habits) of its population (Doyle, 2002). The combination of these two factors is crucial. Thus, size of the market is central, but this by itself does not explain the media system or the future of newspapers. State size matters, argues Hallin, but "we should not expect any simple, consistent pattern in small stale media systems" (2009, p. 101). Interacting with other variables, state size should be considered in the light of the political and historic traditions of the countries that react differently to their environment (Puppis et al., 2009). In an overview of various works addressing the digital challenge of press in small markets, Schlesinger and Benchimol (2015, p. 103) argue that "each nation's political history and public sphere has affected the development of its press system". Specific and individual approaches to countries can then provide useful insights of how smallness is impacting on media industries. 


\section{The Portuguese scenario A general approach}

The size of the population has been used as a relevant variable to evaluate smallness. Portugal has about 10.3 million inhabitants, which has been considered to be a number within the interval that defines small states (Pelinka, 2005). In relative terms, it can also be considered a small state when compared to its close neighbours, Spain and France (Sousa \& Silva, 2009). However, it has an important asset: the Portuguese language is the $6^{\text {th }}$ most spoken native language of the world and falls within the list of the 10 most spoken/written languages in the internet. Portugal is a member of the Community of the Portuguese Speaking Countries, along with Angola, Brazil, Cape Verde, East Timor, Guinea, Mozambique and S. Tomé and Príncipe. Thus, it has a huge potential market, which has not been, so far, explored in a consistent way. The Portuguese public service broadcasts a programming to African audiences through RTP África and a weekly newspaper ${ }^{2}$ has promoted shared editions between Portugal and two African Portuguese speaking countries (Angola and Mozambique), but with no relevant outcomes. From an economic point of view, which is very important given the positive relationship between GDP and advertisement expenditures (Picard, 2008), Portugal has presented a fragile performance (having already called three times for external assistance during the democratic regime).

This heritage negatively influenced newspapers in the afterrevolution period (Mesquita, 1994; Reis \& Nunes, 1994), with the comparative analysis developed by Hallin \& Mancini (2004) placing Portugal within the pluralized pluralist model. The press in Portugal is more elitist and there is a tradition of political clientelism (Hallin \& Papathanassopoulos, 2002), as well as of instrumentalization of media, mostly audiovisual, by businessmen and by politicians. The local press is weak and too dependent

2 The weekly newspaper is "Sol", whose weak economic performance dictated a radical cut in its staff in 2015 (http://observador.pt/2015/11/30/jornais-sol-e-inewshold-sai-e-despede-23-dos-trabalhadores-e-baixa-salarios/) 
on the local interests, such as regional and local politics or other important social and economic local players.

Portugal has four major private media groups, two of them anchored on private television channels and two more focused on the press. The most traditional one is Impresa, created even before the democratic revolution (in 1973) with the launch of a weekly newspaper ("Expresso"), still nowadays one of the most influential newspaper in Portugal. This media group grew in the 1990s with the launch of the first private television channel in Portugal ("SIC"), to which it added several cable channels, and with other press outlets. The second private television channel in Portugal ("TVI") was initially launched by the Catholic Church but its economic and financial difficulties led to its sell out. The television channel ended up in the group of Miguel Paes do Amaral, which was later named Media Capital, mostly a newspaper company. All the press products of the group were sold out until the early 2000s and the group focused its activity in the radio sector and in television. It now belongs to the Spanish group Prisa.

The Global Media group, another of the major media groups in Portugal, has three daily newspapers (one of which a sports newspaper), a Sports cable TV and a national news radio station, apart from other less relevant print products and digital outlets. The origins of this group can be found in the 1950s in the cinema distribution sector, to which were added two major daily newspapers in the early 1990s. It was bought in 2000 by the Portuguese telecommunications company that in 2005 sold the media division to a smaller media group (Controlinveste, that had a sports daily and a sports cable TV) and kept the cinemas network. Controlinveste, later named Global Media group, bought the media outlets very expensively using loans. The years to come were very difficult for the group, which faced an economic crisis and the devaluation of the media assets. The group received an injection of capital by an Angolan Fund and, in 2016, by a Chinese group. The last major private media group is Cofina, whose main assets are a popular daily newspaper (the most sold 
in Portugal), a financial newspaper and a sports daily. It has also launched a cable news TV.

Portugal has five national titles (three quality newspapers, "Público", "Diário de Notícias" and "i", the last one with very small circulation figures, and two tabloids, "Correio da Manhã" and "Jornal de Notícias". Three sports newspapers ("A Bola", "O Jogo" and "Record") are published daily and one financial newspaper ("Jornal de Negócios") is published in the working days of the week. Most of these outlets belong to the media groups presented above, with the exception of one sports newspaper ("A Bola") and one quality newspaper ("Público", that is owned by a major telecommunication group in Portugal) (see table 1).

Table1. Portuguese press groups and operational sectors.

\begin{tabular}{|c|c|c|}
\hline \multirow{2}{*}{$\begin{array}{l}\text { Portuguese } \\
\text { Groups }\end{array}$} & \multicolumn{2}{|l|}{ Activity } \\
\hline & National titles & Other media outlets \\
\hline Impresa & $\begin{array}{l}\text { Expresso (weekly) } \\
\text { Visão (newsmagazine) }\end{array}$ & $\begin{array}{l}\text { Television (SIC and } \\
\text { cable channels) } \\
\text { Magazines } \\
\text { Websites }\end{array}$ \\
\hline Cofina & $\begin{array}{l}\text { Correio da Manhã } \\
\text { (tabloid) } \\
\text { Sábado (newsmagazine) } \\
\text { Record (Sports) } \\
\text { Jornal de Negócios } \\
\text { (financial information) }\end{array}$ & $\begin{array}{l}\text { Cable TV } \\
\text { Magazines } \\
\text { Websites }\end{array}$ \\
\hline $\begin{array}{l}\text { Global } \\
\text { Media }\end{array}$ & $\begin{array}{l}\text { Jornal de Notícias } \\
\text { (tabloid) } \\
\text { Diário de Notícias } \\
\text { (Quality) } \\
\text { O Jogo (Sports) }\end{array}$ & $\begin{array}{l}\text { News radio } \\
\text { Magazines } \\
\text { Websites } \\
\text { Local press }\end{array}$ \\
\hline $\begin{array}{l}\text { Ex- } \\
\text { Newshold }\end{array}$ & $\begin{array}{l}\text { I (Quality) } \\
\text { Sol (weekly) }\end{array}$ & \\
\hline
\end{tabular}

Source: Own elaboration 
One of the problems that has been identified regarding the smallness of the Portuguese market, is the relatively weak position of national media groups in the face of foreign competitors and foreign capital (Silva, 2004; Sousa \& Silva, 2009). For instance, the Spanish media group Prisa is the owner of Media Capital (not listed above because it has not any interests in the press sector), one of the major groups in Portugal (with a networks of radio stations and the audience leader TV station). As previously stated, experiences of internationalization have been weak in terms of the press and, although there is some exportation of audiovisual products, Portugal suffers from strong competition from Brazil in relation to the latter. The 2008 crisis brought about another problematic phenomenon to the media scenario in Portugal: capital of Angolan funds, which raises serious concerns in terms of transparency and editorial freedom (Figueiras \& Ribeiro, 2013; Silva, 2014), entered in media groups, such as Newshold, Cofina and Global Media. Newshold was a group owned by Angolan businessman but the lack of economic sustainability of the newspaper group led the owners to sell out. The phenomenon of Angolan capital inflow is broader than the single media sector, with Portuguese strategic companies from several economic sectors (like energy and telecommunications) being acquired by Angolan investors, but in the case of media companies it is more disturbing as it is "considered a mean of indirectly controlling political life” (Figueiras \& Ribeiro, 2013, p. 521).

\section{The newspaper business}

In general, the Portuguese case has not been considered to differ substantially from the trends of the other western democracies. Most newspapers present negative performances in terms of circulation and advertisement revenues. Advertising figures released by the company which monitors audiences in Portugal (Marktest, 2013) show that the revenues have been decreasing: from 2008 till 2012 newspapers lost $26 \%$ of advertising revenues. Although 2015 global figures for advertising show signs of some recovery, the press still faces decreasing revenues. The last 
available data (Global Media is not a listed company and does not publish its annual report) of media groups' annual reports show a decreasing trend (see table 2), with only one group (Cofina) presenting a positive variation in one year. Classified ads, a major source of revenues for newspapers, are also in a descending curve since two internet-based platforms have concentrated most on the peer-to-peer trading of houses, cars, and other goods and management of the demand/supply of jobs.

Table 2. Advertising revenues variation (\%) in media groups

\begin{tabular}{|c|c|c|c|c|}
\hline \multicolumn{2}{|c|}{ Media groups } & $\begin{array}{l}2013 / \\
2012\end{array}$ & $\begin{array}{l}2014 / \\
2013 \\
\end{array}$ & $\begin{array}{l}2015 / \\
2014\end{array}$ \\
\hline \multirow[t]{2}{*}{ Cofina } & $\begin{array}{l}\text { Newspapers } \\
\text { (Includes revenues } \\
\text { from a cable tv } \\
\text { station) }\end{array}$ & $-9,3 \%$ & $+5,5 \%$ & $-7,9 \%$ \\
\hline & Magazines & $-21.5 \%$ & $+4,7 \%$ & $-8,1 \%$ \\
\hline \multicolumn{2}{|c|}{$\begin{array}{l}\text { Impresa } \\
\text { (Newspapers + magazines) }\end{array}$} & $-6,4 \%$ & $-3,0 \%$ & $-5,6 \%$ \\
\hline
\end{tabular}

Source: Own elaboration from companies' annual reports

From the official figures of newspapers circulation, it is possible to calculate a sharp decrease in Portuguese newspapers circulation. In 2000 , more than 360,000 daily copies were sold in Portugal. In 2015, this figure had suffered a decrease of more than $35 \%$, to a little more than 230,000. A similar trend is visible in sports print news, with losses of $52,5 \%$ in paid circulation from 2000 to 2015. Financial and economic information shows itself more resistant: the two daily newspapers only suffered a loss of $7,5 \%$ in the same period. But in 2016, one the financial newspaper saw its print edition suspended. The recent global economic crisis can be responsible for added losses, but the decreasing trend had started before: in 2007, just before the beginning of the crisis, daily newspapers had already registered a loss of $8,6 \%$ in circulation, when compared to 2000 , thus proving that other variables, such as sociological changes (Franklin, 2008b), are also important. 
Likewise, the profile of the newspapers' buyer is very different, as one tabloid increased its sales while quality newspapers saw their figures going down, with the two titles in Portugal, DN and Público, losing $45 \%$ and $20 \%$ of their circulation respectively.

Newspaper companies are under severe pressure. Media groups to which they belong have presented irregular economic performances, with some losses in annual reports, decreasing revenues and as a result dismissals have affected hundreds of reporters in the past few years (Silva, 2014). Portuguese media groups, such as Impresa and Global Media, were built using heavy loans and this financialization has brought about major challenges for media groups. This is especially the case of Global Media ${ }^{3}$, when indebted opened the doors to Angolan investors.

For the print sector specifically, the total revenues have decreased in the last years: Impresa states a decrease of $8 \%$ in 2013, 7\% in 2014 and 5\% in 2015; Cofina states a decrease of 5\% in $2013,1,5 \%$ in 2014 and $5 \%$ in 2015 . Newspapers suffered the biggest job cuts in the media sector. Print readership is decreasing and, though online audience seems to be in an ascendant curve, companies have not yet come to monetize the increased audiences. Figures for digital revenues in newspapers companies are not widely publicized. Only Impresa mentions them in its annual reports. Claiming to have a $50 \%$ share of the digital market for the newspapers and magazines sector, this group states that digital revenues (circulation and advertising) are $7,2 \%$ of the total revenues (and they were $6,4 \%$ in 2014). So, there has been a slight growth in the capacity of the group to monetize their presence online, but it is clearly a very small share of its total activity.

There has been a growing trend regarding digital subscription, but the total of online subscribers is only 33,000 (for combined daily and weekly press, as well as for financial newspapers), which represents only $10 \%$ of the total circulation of newspapers. These figures are far from compensating the print losses of the newspapers. However, that does not mean that Portuguese people

3 http://observador.pt/especiais/os-novos-donos-de-portugal/ 
are reading less news. According to Eurostat, readership is, in fact, increasing, but people are not willing to pay for it.

In spite of this unwillingness to pay, clearly "legacy" newspapers are strong brands in Portugal. Newspapers titles rank high in the top of "online visits" and "pages views" of news sites there are 7 newspapers are among the 10 most valued sites (while there is only a TV station, none radio station and one aggregator site $)^{4}$. They are also more valued than native digital news outlets. In networking sites, such as Facebook (the most penetrating social network in Portugal), newspapers are also references when compared with news radios or 24 hour news channels (see Table 3).

Table 3. Number of Facebook fans (in millions) for news sites linked to legacy media (as in June 2016)

\begin{tabular}{|l|l|r|}
\hline News organization & "offline" sector & Fans \\
\hline Jornal de Notícias & Press & 1,700 \\
\hline Correio da Manhã & Press & 1,042 \\
\hline Sic Notícias & TV & 1,032 \\
\hline Público & Press & 1,011 \\
\hline Diário de Notícias & Press & 0,800 \\
\hline TVI 24 & TV & 0,564 \\
\hline TSF & Radio & 0,383 \\
\hline RTP Notícias & TV & 0,283 \\
\hline RR & Radio & 0,228 \\
\hline
\end{tabular}

Source: Own elaboration from official media Facebook pages

The daily newspaper "Jornal de Notícias" was the first one to offer a digital version, back in 1995, and at that time the digital strategy of Portuguese newspapers was to provide the information for free.Nowadays, the four more important newspapers have a paywall. While Público has a metered system, Correio da Manhã, Diário de Notícias and Jornal de Notícias have exclusive news for subscribers. The latter two outlets also have daily newsletters

$4 \mathrm{http}: / /$ net.marktest.pt/netscope/rankings-netscope/ranking-netscope-de-abrilde-2016/ 
for registered readers. The combination of registration and subscription allows newspapers to build a more consistent database of their loyal consumers and thus can therefore present higher value to the advertisers.

In terms of content, besides providing exclusive news for their readers, other strategies are in place, such as the production of videos (a clear option for Jornal de Notícias) or the provision of content targeted to a specific demographic profile, like the "P3" site from Público, intended mainly to the younger digital natives. For a weekly print newspaper such as "Expresso" the solution to provide a continuous digital presence was found in a daily online newspaper, only accessible through a code distributed in the print weekly edition.

The traditional newspaper business models that combined paid circulation with advertising revenues is giving way to more pluralized ways to monetize assets. And it is not only a question of including the digital operation. Newspapers companies are engaging in other strategies to stay relevant to both readers and advertisers. Clearly, brands are strong assets for newspapers companies in the news world and firms have used the brand to promote conferences and special editions. Firms have also created online platforms for classified advertisements. Centenarian newspapers (like Diário de Notícias and Jornal de Notícias) have valuable archives, namely in terms of photography, that are being monetized. Non-traditional marketing, websites, multimedia productions and events organization are other visible strategies of the newspapers firms to diversify the source of revenues.

\section{Final remarks}

Newspapers are engaging in digital strategies and in other forms to attract non-traditional revenues, such organizing conferences, in order to stay relevant to readers and to monetize their assets - although they have not, until now, been able to reverse the continuous decline of their overall revenues. Most of the firms are still experimenting with different approaches (such as paywalls) and their success (or failures) will only be proven with 
more time. While there has been some discussion and alerts given by newspapers managers on the need to make news aggregators (such as Google) start paying for the content they use to attract advertising, no steady steps have been taken to this point - nor can it be a solely national strategy only given the international nature of these companies.

Although Portuguese is a prevailing language with a potential reach that overcomes national boundaries (and thus of enlarging markets), there has not been successful experiences of internationalization of the press. More efforts in connecting with the other Portuguese speaking countries, namely in terms of the content provided, have to be done if newspapers are to reach wider audiences than the ones of the national Portuguese boundaries. This possible internationalization should not be dismissed since, on one side, globalization has increased the number of issues that are of potential interest to readers of different countries and the Portuguese press seems more prepared to approach them, as the other Portuguese-speaking countries are still developing countries. On the other side, if smallness can be synonym to more specific cultural contents, the Portuguese press can present some kind of appeal to Portuguese speaking countries who share a cultural and social heritage bound by History. What has been a limitation in the past can turn into a competitive advantage as smallness may be converted into a close coverage of the issues of this community.

Portuguese newspapers companies are facing troubled times. In common with elsewhere, they are facing a continuing decline in newspaper sales and the migration of online advertising to other platforms such as Google and Facebook. This is particularly serious in a small country with historical low levels of readership and strong economic weaknesses. State subsidies to the press do not tend to be well accepted due to the also historical trend of the politicization of media by politicians; which, at this point, apparently leaves the solution to the market.

In spite of the solution to the Portuguese press sustainability seeming to rely solely on the market side, it should not be an issue to analyze only from the revenue and profit point-of-view. 


\section{All over the past decades, the press has been performing a civic role that is essential to a democratic culture and the functions it performs should be closely scrutinized before any society is ready to give up on them for economic reasons only.}

\section{References}

Berte, K., \& De Bens, E. (2008). Newspapers go for advertising! Challenges and opportunities in a changing media environment. Journalism studies, 9(5), 692-703.

Casero-Ripollés, A., \& Izquierdo-Castill, J. (2013). Between decline and a new online business model: the case of the Spanish newspaper industry. Journal of Media Business Studies, 10(1), 63-78.

Chambers, T. (2003). Structural changes in small media markets. The journal of media economics, 16(1), 41-59.

Dekavalla, M. (2015). The Scottish newspaper industry in the digital era. Media, Culture \& Society, 37(1), 107-114.

Doyle, G. (2002). Media ownership: The economics and politics of convergence and concentration in the UK and European media. London: Sage.

Doyle, G. (2013). Re-invention and survival: newspapers in the era of digital multiplatform delivery. Journal of Media Business Studies, 10(4), 1-20.

Figueiras, R., \& Ribeiro, N. (2013). New Global Flows of Capital in Media Industries after the 2008 Financial Crisis: The Angola-Portugal Relationship. The International Journal of Press/Politics, 18(4), 508-524

Fiztgerald, S. W. (2012). Corporations and cultural industries: Time Warner, Bertelsmann, and News Corporation. Lanham, MD: Lexington Books.

Franklin, B. (2008a). Pulling newspapers apart: analysing print journalism. London: Routledge.

Franklin, B. (2008b). The future of newspapers. Journalism Studies, 9(5), 630-641.

Hallin, D. (2009). Comment - State as a Variable in Comparative Analysis, International Communication Gazette, 71(1-2), 101-103.

Hallin, D. C., \& Mancini, P. (2004). Comparing media systems: Three models of media and politics. Cambridge: Cambridge University Press.

Hallin, D. C., \& Papathanassopoulos, S. (2002). Political clientelism and the media: southern Europe and Latin America in comparative perspective. Media, culture \& society, 24(2), 175-195.

MacGregor, P. (2007). Tracking the online audience. Journalism Studies, 8(2), 281-298.

Marktest (2013). Anuário de Media e Publicidade: 2013. Grupo Marktest.

Mesquita, M. (1994). Os meios de comunicação social - o universo dos media entre 1974 e 1986. In A: Reis (Coord.) Portugal 20 anos de democracia. Lisboa: Círculo de Leitores

Meyer, P. (2009). The vanishing newspaper: saving journalism in the Information Age (Updated 2nd Edition). Columbia: University of Missouri Press.

Nguyen, A. (2013). Online News Audiences: the challenge of web metrics. In: Allan, S. \& Fowler-Walt (Eds.) Journalism: New Challenges, Poole: CJCR Centre for Journalism \& Communication Research, Bournemouth University, 146-161. 
Parasie, S., \& Cointet, J. P. (2012). La presse en ligne au service de la démocratie locale. Revue française de science politique, 62(1), 45-70.

Pelinka, A. (2005). Vergleich politischer Systeme (Vol. 2726). Grove/Atlantic, Inc..

Picard, R. G. (2010). Value Creation and the future of news organizations. Lisboa: Formalpress | Media XXI.

Picard, R. G. (2008). Shifts in newspaper advertising expenditures and their implications for the future of newspapers. Journalism Studies, 9(5), 704-716.

Picard, R. G. (1988). Measures of concentration in the daily newspaper industry. Journal of Media Economics, 1, 61-74.

Prado, E. (2015). The press in Catalonia: between the digital challenge and nation building. Media, Culture \& Society, 37(1), 134-143.

Puppis, M. (2009). Media regulation in small states. International communication gazette, 71 (1-2), 7-17.

Puppis, M., d'Haenens, L., Steinmaurer, T., \& Künzler, M. (2009). The European and global dimension taking small media systems research to the next level. International communication gazette, 71(1-2), 105-112.

Reis, A. \& Nunes, J. M. (1994). Os meios de comunicação social - breve síntese sobre a evolução dos media no período 87-94. In A. Reis (Coord.) Portugal 20 anos de democracia. Lisboa: Círculo de Leitores.

Schlesinger, P., \& Benchimol, A. (2015). Small nations, the press and the digital challenge. Media, Culture \& Society, 37(1), 101-106.

Schudson, M. (2008). Why Democracies Need an Unlovable Press. Cambridge: Polity Press.

Schulhofer-Wohl, S., \& Garrido, M. (2013). Do newspapers matter? Short-run and longrun evidence from the closure of The Cincinnati Post. Journal of Media Economics, 26(2), 60-81.

Siles, I., \& Boczkowski, P. J. (2012). Making sense of the newspaper crisis: A critical assessment of existing research and an agenda for future work. New Media \& Society, 14(8), 1375-1394.

Silva, E. C. (2014) Crisis, financialization and regulation: the case of media industries in Portugal. The Political Economy of Communication, 2(2), 47-60.

Silva, E. C. (2004). Os donos da Notícia. Porto: Porto Editora.

Sousa, H., \& e Silva, E. C. (2009). Keeping Up Appearances Regulating Media Diversity in Portugal. International Communication Gazette, 71(1-2), 89-100.

Tandoc Jr., E. C. (2014) Why web analytics click. Journalism Studies, DOI: 10.1080/1461670X.2014.946309

Tremblay, G. (2014). iPublish or perish: challenges facing the Québec press in the digital age. Media, Culture \& Society, DOI: 10.1177/0163443714553564

Veenendaal, W. P., \& Corbett, J. (2014). Why small states offer important answers to large questions. Comparative Political Studies, 0010414014554687.

Wasserman, H. (2008). Attack of the killer newspapers! Journalism Studies, 9(5), 786797.

\section{(c) $(1)(5)$}

Published under a Creative Commons Licence

"Attribution - NonCommercial - NoDerivs 4.0 International"

(CC BY-NC-ND) 